\title{
The Common Fisheries Policy: A Difficult Compromise Between Relative Stability and the Discard Ban
}

\author{
José Manuel Sobrino and Marta Sobrido
}

\section{Introduction}

The fishing opportunities of the European Union (EU) ${ }^{1}$ vary annually, mainly in response to biological considerations. To ensure the greatest possible stability, for over 30 years the allocation of EU fishing opportunities to its Member States (MSs) has been based on a predictable share of the stocks for each MS, known as relative stability (RS).

In December 2013, Regulation (EU) No 1380/2013 of the European Parliament and the Council on the Common Fisheries Policy was adopted. ${ }^{2}$ The new regulation keeps RS as a criterion for allocating fishing opportunities to MS and also bans discards, which are catches returned to the sea. ${ }^{3}$ Implementing the discard ban is a major challenge for mixed fisheries in which more than one species is present and where different species are likely to be caught in the same fishing operation, ${ }^{4}$ e.g., cod, haddock, whiting, and saithe in Northwest Atlantic waters.

\footnotetext{
${ }^{1}$ For easier reading we shall refer to European Union (EU). But for EU we also mean the European Economic Community (EEC, 1958-1993) and the European Community (EC, 1993-2009). The EEC came into being in 1958. With the entry into force of the Treaty on European Union in November 1993, the EEC became the EC. And with the introduction of the Lisbon Treaty in December 2009, the EU replaced and succeeded the EC.

${ }^{2}$ Regulation (EU) No 1380/2013 of the European Parliament and of the Council of 11 December 2013 on the Common Fisheries Policy, amending Council Regulations (EC) No 1954/2003 and (EC) No 1224/2009 and repealing Council Regulations (EC) No 2371/2002 and (EC) No 639/2004 and Council Decision 2004/585/EC. OJ 2013 L 354/22-61.

${ }^{3}$ Definition of discards: article 4.1.10; ibid.

${ }^{4}$ Definition of mixed fisheries: article 4.1.36; ibid.
}

J.M. Sobrino $・$ M. Sobrido $(\bowtie)$

University Institute of European Studies "Salvador de Madariaga", University of A Coruña,

Campus de Elviña, s/n, A Coruña 15071, Spain

e-mail: j.sobrino@udc.es; marta.sobrido@udc.es 
The aim of this paper is to examine the compromise between RS and the discard ban.

\section{Origin and Enshrining of Relative Stability}

The origin and evolution of the Common Fisheries Policy (CFP) is closely linked to the evolution of international fisheries law (in particular, the creation of the exclusive economic zone) ${ }^{5}$ and the enlargement of the EU (mainly the first and third extension, which included the major European fishing states). Knowledge of both processes is also essential for understanding the rationale behind and the resulting form of $\mathrm{RS}$.

The first EU fisheries legislation, which among other things established the "equal access principle," was adopted at the beginning of the 1970s as a preliminary step for the negotiations that would result in the first enlargement of the EU, ${ }^{6}$ involving the major fishing states of the United Kingdom (UK), Ireland, Denmark (Danish accession included Greenland but not the Faroe Islands), ${ }^{7}$ and Norway, although the latter did not finally join. RS emerges shortly after, in connection with the outcome of the accession negotiations that enabled that first enlargement. But it is also closely linked to two other factors: the establishment of the exclusive economic zone and the third enlargement of the EU. In relation to the first factor we must recall how, in reaction to certain non-EU countries asserting jurisdiction

\footnotetext{
${ }^{5}$ See Rey Aneiros (2001) and Sobrino Heredia (2003).

${ }^{6}$ The EU has had competence to adopt legislation on fisheries from the outset (EEC Treaty, 1957), but fishing was not a priority for MSs then (France, Germany, Italy, Belgium, Netherlands and Luxembourg). Moreover, fishing mostly took place in what were then waters of the high seas. The first step was taken in 1966, with a report from the Commission. In 1968, three draft regulations appeared that eventually led to the adoption in 1970 of two regulations-Council Regulations (EEC) Nos 2141/70 and 2142/70 — which, among other things, introduced the "equal access principle". In accordance with this principle the fishing regulation applied by each MS in its maritime waters-waters under its sovereignty or within its jurisdiction-must not lead to differences in the treatment of other MSs. Churchill and Owen (2010), pp. 4-6, state that MSs wanted an acquis for fisheries before starting negotiations with the four candidate states and, in fact, the two regulations cited were adopted the day before formal negotiations started with these states.

${ }^{7}$ Treaty of Accession of Denmark, Ireland and the United Kingdom (1972); OJ 1972 L 73; MSs of the EU since 1 January 1973. Both Greenland and the Faroe Islands are part of Denmark, but when Denmark joined the EU in 1973, the Faroe Islands decided to remain outside precisely because of fishing: "the Faroese have not found it their interest to become subject to the Common Fisheries Policy" (The Government of the Faroe Islands, http://www.government.fo/foreign-relations/mis sions-of-the-faroe-islands-abroad/the-mission-of-the-faroes-to-the-european-union/the-faroeislands-and-the-european-union/). The Faroe Islands is like a third country with respect to the EU. As for Greenland, it joined the EU in 1973 as part of Denmark but withdrew from it in 1985 as result of a referendum held in 1982. Since then, Greenland is part of the OCT (Overseas Countries and Territories; articles 198-204 TFEU).
} 
over their waters out to 200 miles, the EU adopted very similar fishing areas from $1977 .{ }^{8}$ Moreover, the EU took responsibility for managing fishing rights in these new waters and also the fishing rights of EU vessels in the waters of third states. With regard to the second factor, the negotiations concerning what would become the third enlargement of the EU involved states with major fishing interests such as Spain and Portugal. ${ }^{9}$ After the first enlargement, the UK and Ireland were by far the largest EU fishing powers, ${ }^{10}$ a position that would later be occupied by Spain, although it, like Portugal, did not have great resources in its waters. Against this backdrop, most MSs wanted to have a European system of fisheries management established before starting negotiations with these two countries. ${ }^{11}$

\subsection{Origin of Relative Stability}

In November 1976, the Council adopted the "Hague Resolution," which deals with the external aspects (affirmation of the competence of the EU to negotiate with third countries) ${ }^{12}$ as well as internal aspects (affirmation of competence of the EU for the

\footnotetext{
${ }^{8}$ Joint action by MSs concerning the waters of the North Sea and North Atlantic. For the evolution of the EU position, and that of its members, on the establishment of the exclusive economic zone within the framework of the III United Nations Conference on the Law of the Sea (1973-1982), see Treves (1976).

${ }^{9}$ Portugal submitted a formal application for membership in the EU on March 28, 1977. Spain did the same 4 months later, on 28 July 1977. With regard to Spain, the letters exchanged in July 1977 between the Spanish Prime Minister and the Chairman of the European Communities on Spain's request to start negotiating its integration can be found in Revista de Instituciones Europeas 4 (1977) 1031-1036. The negotiations culminated in 1985 in the Treaty of Accession of Spain and Portugal (1985); OJ 1985 L 302. Spain and Portugal have been MSs of the EU since 1 January 1986.

${ }^{10}$ In 1981 , when the EU was formed by 10 countries, almost $90 \%$ of EU resources were captured by the UK (64\%) and Ireland (25\%); see Lostado i Bojo (1985), p. 41.

${ }^{11}$ As stated by Churchill and Owen (2010), pp. 11-14, Spain and Portugal had large fleets (the Spanish fleet was nearly $3 / 4$ the size of the entire EU fleet, at the time composed by ten MSs), and the waters under the jurisdiction of these two states did not have many resources because their continental shelves - not in the legal but the geological sense-are narrow, and waters located on the continental shelves are the richest in fishery resources. The Commission then spoke of an "imbalance in the fisheries sector between the tonnage of the Spanish fleet and the fishing zones available to Spain"; European Commission, "Opinion on Spain's application for membership", sent to the Council by the Commission on 29 November 1978; available at Bulletin of the European Communities, Supplement 9/78 (1978) 16. On the other hand, Portugal and Spain had sufficient fisheries access agreements with third countries with which the EC had no agreements; see Sobrino Heredia (1990).

${ }^{12}$ Council Resolution of 3 November 1976 on certain external aspects of the creation of a 200-mile fishing zone in the Community with effect from 1 January 1977; OJ 1981 C 105/1.
} 
adoption of conservation measures in EU waters $)^{13}$ that result from the creation, in 1977, of the 200-mile fishing zone. In this resolution, which was published late ${ }^{14}$ and incomplete, ${ }^{15}$ the Council states that the CFP must take into account the vital needs of regions where local populations depend greatly on fishing and related industries. Known as the "Hague Preferences," this provision is specifically directed towards Ireland and northern parts of the UK. ${ }^{16}$ Despite its open wording, these "preferences" are a recognition that must be understood in the context of the negotiations with the UK and Ireland. Therefore, they cannot be automatically extended to other areas with similar needs; it became clear during the subsequent accession of new states.

The full implementation of the Hague Resolution via a specific distribution among MSs required years of difficult negotiations. ${ }^{17}$ Finally, in 1983, the Council adopted a regulation ${ }^{18}$ and, based on it, made the first allocation among the MSs ${ }^{19}$

\footnotetext{
${ }^{13}$ Annex VI to the Hague Resolution of 3 November 1976; text reproduced in Opinion of Advocate General Reischl delivered on 11 September 1979, France v UK, 141/78, ECLI:EU:C:1979:202, p. 2945. Regarding EU fishing regime and third states, see Del Vecchio (1982) and Meseguer Sánchez (1981).

${ }^{14}$ Not published until 1981 (OJ 1981 C 105/1). In 2001, the Advocate General Alber drew attention to its late and incomplete publication; see Opinion of Advocate General Alber delivered on 13 November 2001, Spain v Council, joined cases C-61/96, C-132/97, C-45/98, C-27/99, C-81/ 00 and C-22/01, ECLI:EU:C:2001:602, footnote 7.

${ }^{15}$ The Hague Resolution had eight annexes. However, in the Official Journal of the European Union (OJ) only Annex I, on the external aspects, was published. In 1998 the Court of Justice of the European Union (CJEU) drew attention to this incompleteness. See Judgment of the Court of 19 February 1998, NIFPO and Northern Ireland Fishermen's Federation v Department of Agriculture for Northern Ireland, C-4/96, ECLI:EU:C:1998:67, paragraph 5. The Advocate General in this same case noted that the explanation given by the Council to justify this defect was that some of its annexes contained confidential material regarding instructions given by the Council to the Commission concerning future negotiations by the EU with non-member countries and international organisations (see Opinion of Advocate General La Pergola issued on 30 September 1997, case C-4/96, cit., ECLI:EU:C:1997:444, point 7). In that judgment, the CJEU reproduces the text of Annex VII (see the judgment in case C-4/ 96, cit., paragraph 4). And many years before, the Advocate General Reischl had reproduced the text of Annex VI (see Opinion in case C-141/78, cit., p. 2945).

16 “. (...) the expression 'northern parts of the United Kingdom' for the purposes of the Hague Preferences comprises Scotland, Northern Ireland, the Isle of Man, and that part of England between the ports of Bridling- ton and Berwick"; Opinion in case C-4/96, cit., footnote 9.

${ }^{17}$ See Holden (1985), point 6 "Allocation Between Member States of the EEC". Holden was at that moment Directorate General for Fisheries Commission of the European Communities.

${ }^{18}$ Council Regulation (EEC) No 170/83 of 25 January 1983 establishing a Community system for the conservation and management of fishery resources; OJ 1983 L 24/1-13. This regulation establishes that the volume of the catches available to the EU must be shared across the MSs in a manner which assures each MS relative stability in fishing activities for each of the stocks considered (art. 4.1) with the notion of relative stability understood in accordance with the Hague Preferences (recitals 6-7).

${ }^{19}$ Council Regulation (EEC) No 172/83 of 25 January 1983 fixing for certain fish stocks and groups of fish stocks occurring in the Community's fishing zone, total allowable catches for 1982, the share of these catches available to the Community, the allocation of that share between the Member States and the conditions under which the total allowable catches may be fished; OJ 1983 L 24/30-67.
} 
stating that three criteria were considered for doing this: the traditional fishing activities, the specific needs of areas particularly dependent on fishing and its dependent industries (the Hague Preferences), and the loss of fishing potential in the waters of third countries. ${ }^{20}$ With regard to the Hague Preferences for Ireland, Northern Britain, and Greenland (the latter until it left the EU in 1985), Ireland, the UK, and Denmark were assured that their fishing opportunities for certain species would reach a minimum threshold, on the understanding that this threshold would be in absolute terms and not a percentage. As noted above, these preferences were not the result of an objective study of the special needs of European fishing territories but the result of a negotiation. ${ }^{21}$

\subsection{Enshrining Relative Stability}

This allocation formula laid down in $1983^{22}$ continues to take place; it appeared in subsequent reforms $(1992,2002,2013)^{23}$ and is in the current regulation, despite the proposed amendment put forward by the European Commission's Green Book on the reform of the CFP (2009). ${ }^{24}$

\footnotetext{
${ }^{20}$ Ibid. recital 3. These criteria, which were set by the Council in 1980 without further details on their application or how much weight was to be placed on each criterion (Council declaration of 30 May 1980 on the common fisheries policy, OJ 1980 C 158/2) were interpreted by the Commission, which presented a mathematical model that took into account the three criteria and served as a starting point for the allocation of quotas, stock by stock. As Holden (1985) states, the Commission interpreted what should be understood by traditional fishing activities ("average catches in the period 1973-78, less industrial by-catches beyond permitted limits and human consumption species caught directly for reduction to meal and oil"), the specific needs of areas particularly dependent on fishing and its dependent industries ("For Greenland: a major share of the catch possibilities in Greenland waters; For Ireland: doubling of the 1975 catches by 1978; For north Britain: maintaining a minimum catch possibility equal to the landings in 1975 by vessels less than $24 \mathrm{~m}$ long at ports in northern Ireland, Scotland and along the east coast of England as far south as Bridlington"), and the loss of fishing potential in the waters of third countries ("the difference between what a Member State is actually allowed to catch and what it would have caught if there had been no extension to 200-mile limits. What it would have caught is calculated as its average percentage share of the particular stock for the period 1973-76 multiplied by the TAC, if known, or the estimated TAC, otherwise").

${ }^{21}$ Penas Lado (2016), p. 28, points out that, in exchange for this guarantee, the UK and Ireland agreed to lower TACs - understood as the percentage applied in the context of the RS - than they wanted.

${ }^{22}$ Allocation formula laid down in Regulation 172/83, cit.

${ }^{23}$ Council Regulation (EEC) No 3760/92 of 20 December 1992 establishing a Community system for fisheries and aquaculture; OJ 1992 L 389/1-14; see recitals 12-14. Council Regulation (EC) No 2371/2002 of 20 December 2002 on the conservation and sustainable exploitation of fisheries resources under the Common Fisheries Policy; OJ 2002 L 358/59-80; see recitals 16-18. Regulation 1380/2013, cit., see recitals 35-37.

${ }^{24}$ European Commission, Green Paper of 22 April 2009-Reform of the Common Fisheries Policy, $\operatorname{COM}(2009) 163$ final; Green Paper 2009, hereinafter. See point 5.3.
} 
However, it has been completed as a result of new accessions and distribution of more species. On the one hand, since 1983 new states have acceded to the EU, including major fishing nations such as Spain and Portugal. When joining the EU, each new state accepts the acquis communautaire and therefore also RS, not as an underlying principle to ensure a distribution that tends to provide stability but as the specific percentages determined in $1983 .^{25}$ The incorporation of a new state does not entitle that state to require a review of the percentages set when it was not part of the EU. With regard to these species, the new MS only gets what negotiates in its accession treaty. ${ }^{26}$ On the other hand, in the distribution of 1983, not all species from all areas were included, and over time it has been necessary to offer new fishing opportunities. This decision is made by the Council, taking into account the "interests" of the states, ${ }^{27}$ a notion that does not necessarily take into account, if any, the historical catches of the MSs for that stock zone. ${ }^{28}$

In brief, the current allocation percentages are established as follows: first, by taking into account the percentages established in 1983, if necessary with the application of the Hague Preferences, ${ }^{29}$ e.g., the allocation of cod and whiting quotas in ICES division VIIa (Irish Sea) ${ }^{30}$ second, based on the percentages set forth in the Acts of Accession of states that adhered after 1983, e.g., the allocation of anchovy quotas in ICES division VIII (Bay of Biscay), ${ }^{31}$ and third, in accordance with the

\footnotetext{
${ }^{25}$ As stated expressly by the CJEU. Judgment of the Court of 30 March 2006, Spain v Council, C-87/03 and C-100/03, ECLI:EU:C:2006:207, paragraphs 28-29.

${ }^{26}$ For new states, the application of RS is not based on the three criteria taken into account in the regulations of 1983; rather, it is only based on historical catches. Penas Lado (2016), p. 27.

${ }^{27}$ Art. 16.1 of Regulation 1380/2013: “. . . The interests of each Member State shall be taken into account when new fishing opportunities are allocated". And in the same sense, formerly, the regulations from 1992 and 2002; see article 8.4.iii) of Regulation 3760/92, and article 20.2 of Regulation 2371/2002.

${ }^{28}$ As stated expressly by the CJEU, the allocation of new fishing opportunities among MSs requires the assessment of a complex economic situation for which the Council enjoys a wide discretionary power (Judgments in cases C-87/03 and C-100/03, cit., paragraph 38). That is not always harmonious process.

${ }^{29}$ Penas Lado (2016), p. 348, points out that the Hague Preferences have been applied continuously although not always harmoniously owing to the resistance of negatively affected MSs. This author explains that its application is not automatic but established within a negotiating framework, and often only $50 \%$ is applied (i.e., the average between what the UK and/or Ireland would receive by applying RS and what they would obtain under the Hague Preferences).

${ }^{30}$ The distribution of these quotas and the application of the Hague Preferences were specifically addressed in case C-4/96. Judgment of case C-4/96, cit., paragraph 18: "Under that mechanism, Ireland and the United Kingdom are granted annual quotas calculated on the basis of the mid-point between the notional quotas resulting from the application of the 1983 allocation keys alone and the notional quotas corresponding to their Hague Preferences".

${ }^{31}$ The Act concerning the conditions of accession of Spain (cit., arts. 161.1.f and 162) established that $90 \%$ of the quota for anchovy in the Bay of Biscay correspond to Spain and the remaining $10 \%$ to France. For example, the TAC of 22,500 tonnes for the EU in the Gulf of Biscay in 2016 is distributed as follows: 22,500 tonnes for Spain and 2500 for France; Council Regulation (EU) 2016/72 of 22 January 2016, OJ 2016 L 22/42.
} 
percentages for new fishing opportunities, e.g., the angler fish quota in ICES division IV (Norwegian waters), which was allocated for the first time in $2005 .^{32}$

The resulting percentages of these three processes constitute the RS distribution key.

\section{The Nature of Relative Stability}

RS is a criterion of distribution that, as its name suggests, aims to ensure the greatest possible stability. Given the constraints surrounding the setting of quotas, it is a relative stability as opposed to an absolute stability. Furthermore, its implementation as a distribution key does not guarantee the relative stability of the situation prior to its implementation but a future relative stability (1).

The mechanisms for allowing flexibility in this distribution key exclude fishing communities as direct beneficiaries, and RS is established as a guarantee of stability only for states (2). RS is a mandatory distribution key, albeit one susceptible to modification (3).

\subsection{Future Predictability}

Due to the difficult situation in the fisheries sector (structural problems of great socioeconomic impact), from the beginning of the CFP it was decided that this area would not be subject to the rules governing the single market in the EU for economic activities. $^{33}$

To ensure the maximum stability, it was agreed that the EU itself would distribute the fishing opportunities among states (leaving the distribution of national quotas among fishing operators to each state, according to the criteria deemed appropriate). It was also decided that such a distribution would be the same every year, not in absolute terms but at least in relative terms. The distribution cannot be the same in absolute terms because the EU fishing opportunities (in EU waters, in waters subject to the sovereignty or jurisdiction of third countries, and in

\footnotetext{
${ }^{32}$ This allocation took place with the Council Regulation (EC) No 27/2005 of 22 December 2004, OJ 2005 L 12/1. Its character of "new fishing opportunity" was confirmed by the CJEU in Case C 141/05; 5; Judgment of the Court of 8 November 2007, Spain v Council, C-141/05, ECLI:EU: C:2007:653, paragraph 90.

${ }^{33}$ See European Commission, Green Paper on the future of the Common Fisheries Policy, COM (2001) 135 final; Green Paper 2001, hereinafter; section 5.1.4.1. This exception to the single market has received great criticism from many quarters (authors, authorities, etc.). For instance, by a region highly dependent on fishing, Galicia (Spain); see Xunta de Galicia, Declaration by the Autonomous Government (Xunta) of Galicia on the Principles of the European Union in the Future Common Fisheries Policy (Santiago de Compostela: Xunta de Galicia, 2002).
} 
international waters) are not the same every year. It varies depending on the biological status of fisheries and on the outcome of agreements with third parties.

Furthermore, its implementation as a distribution key does not guarantee the relative stability of the situation prior to its implementation-not for those who were MSs in 1983 and not for new states that have joined since then. What is guaranteed is the stability of the original terms agreed upon, which amounts to a future stability.

In this respect, the Hague Preferences deserve special mention, although some states_-such as Belgium, Denmark, Germany, the Netherlands, and France - are manifestly against them. The EU regulation refers to the Hague Preferences as an element that integrates RS. It was like this at the beginning (1983) ${ }^{34}$ and has continued to be so in subsequent regulations $(1992,2002,2013) .^{35}$ The Hague Preferences guarantee preferential treatment to Ireland and the UK for certain fisheries. When the application of RS would result in total allowable catches (TACs) for the UK and Ireland in certain fisheries below the minimum originally agreed upon, these states may request the application of the Hague Preferences. This system, which is applied by the Council, results in higher TACs for Ireland and the UK than they would otherwise receive. Inevitably, this occurs at the expense of other states that have a share in the fisheries in question. ${ }^{36}$

\subsection{The States as Beneficiaries of Relative Stability}

RS is a guarantee, a guarantee of stability. But it is a guarantee for states, ${ }^{37}$ not a guarantee for the economic actors involved in fishing. For this reason, the situation of the latter is irrelevant from a legal point of view.

Despite being presented as a criterion for safeguarding the interests of the fishing industry and fishing communities, ${ }^{38}$ the fact is, as the European Commission warned in 2009, RS no longer provides a guarantee that fishing rights remain

\footnotetext{
${ }^{34}$ Regulation 170/83, cit., recitals 35-37.

${ }^{35}$ Regulation 3760/92, cit., recitals 12-14. Regulation 2371/2002, cit., recitals 16-18. Regulation 1380/2013, cit., recitals 35-37.

${ }^{36}$ See Parliamentary questions (European Parliament); Answer given by the Commission to the written question E-0139/08, 13 March 2008.

37، The principle of relative stability has, since 1983, provided assurances to the Member States with regard to the share of quotas, thus avoiding annual repetitions of a political debate on the allocation key, which would have made the decision-making on TACs even more complicated..." Green Paper 2001, cit.; section 5.1.4.1.

${ }^{38}$ According to the current regulation: " 35 . In view of the precarious economic state of the fishing industry and the dependence of certain coastal communities on fishing, it is necessary to ensure the relative stability of fishing activities by allocating fishing opportunities among Member States, based on a predictable share of the stocks for each Member State. 36. Such relative stability of fishing activities (...) should safeguard and take full account of the particular needs of regions where local communities are especially dependent on fisheries and related activities (...)"; Regulation 1380/2013, cit., recitals 35-36.
} 
with their fishing communities. RS itself has promoted a series of practices that has led to RS no longer providing this guarantee. This, along with other factors, has contributed to a current discrepancy between the quotas allocated to MSs and the actual needs and uses of their fleets. ${ }^{39}$ However, this amounts to a merely political argument, not a legal one.

This argument would stand as justification for changing the law (through the appropriate legislative procedure). Indeed, in the debate prior to the last reform, the Commission used it to propose amendments. ${ }^{40}$ However, as these amendments did not prosper, this argument does not seem to be considered valid legal grounds for bringing an action before the Court of Justice of the EU (CJEU). In this regard, we must also remember that, in a case of a violation of RS, the CJEU does not recognize the right of fishing operators to be compensated for any damage that such a violation may cause to them. ${ }^{41}$

\subsection{Allocation Formula Contained in the Derived Legislation}

The CJEU has had to rule on $\mathrm{RS}^{42}$ and in doing so uses the term "principle,"43 which is also used by many authors. However, when identifying its contents, the CJEU qualifies RS as a "fixed percentage" and as an "allocation formula originally laid down [that] will continue to apply as long as an amending regulation has not been adopted." 44

While we do not intend here to examine, or reflect upon, the principles of EU law, ${ }^{45}$ we must keep in mind the following: like international and national laws, EU law has an unwritten component consisting of general principles that take precedence not over primary law but over secondary law. Some of these principles are rooted in principles of international law or national law (e.g., the presumption of

\footnotetext{
${ }^{39}$ Green Paper 2009, cit., section 5.3.

${ }^{40}$ Ibid.

41 “88. (...) the principle of relative stability concerns only relations between Member States, it cannot confer individual rights upon private parties, the infringement of which would give rise to a right to compensation (...). 89. (...) The principle of relative stability does not therefore confer on fishermen any guarantee that they can catch a fixed quantity of fish, since the requirement of relative stability must be understood as meaning merely maintenance of a right to a fixed percentage for each Member State in that distribution". Judgment of the Court of First Instance of 19 October 2005, Cofradía de pescadores de "San Pedro" de Bermeo and Others v Council, T-415/03; ECLI:EU:T:2005:365; paragraphs 88-89.

${ }^{42}$ Franckx (2012) clearly identifies RS as one of the main of the many fishery issues that the CJEU has had to deal with. For more on this case law, see also: Le Bihan (2003), Sobrido-Prieto (2013), and Sobrino Heredia and Rey Aneiros (1997).

${ }^{43}$ E.g., Judgment in case C-141/05, cit., paragraphs 11, 44, 48, 62, 85, 87.

${ }^{44}$ Ibid., paragraph 86.

${ }^{45}$ See Sobrino Heredia (2009).
} 
innocence), ${ }^{46}$ while others are specific principles of EU law (e.g., the principle of institutional balance). ${ }^{47}$ These principles have been articulated by the CJEU through an interpretive analysis extracted from written EU law and also international law and the national law of the MSs. The CJEU does not create these principles but extracts them from these sources.

Alongside these general principles, each area of the EU also has its peculiarities. In fisheries management, for example, certain principles such as good governance ${ }^{48}$ and the precautionary principle $\mathrm{e}^{49}$ are particularly important. RS, however, is not presented as a principle. The legislative acts that give substance to RS qualify it as a "notion" 50 or, in its current regulation, as a "concept.",51

What is noteworthy is its specific and binding nature and the possibilities for change, flexibility, and even repeal. RS is not a guiding principle to ensure a distribution that tends to provide stability but specific percentages imposed as binding that form part of the acquis communautaire. Even for new fishing opportunities, the decision made by the Council is not necessarily based on stability. ${ }^{52}$

$\mathrm{RS}$ is a distribution key negotiated between MSs that is laid down in the secondary legislation of the EU.

The implementation of RS as percentages is the result of negotiation between the MSs. Perhaps the best example of this negotiation is the Hague Preferences. Although presented as a safeguard for the benefit of the most vulnerable regions, in practice they are not applied in benefit of any region that may be classified as such (regions where the local populations are especially dependent on fisheries and related activities) but only in the case of Ireland and the UK. This negotiating

\footnotetext{
${ }^{46}$ E.g. Judgment of the Court of 21 January 2016, "Eturas" UAB and Others $v$ Lietuvos Respublikos konkurencijos taryba, C-74/14, ECLI:EU:C:2016:42, paragraph 38.

${ }^{47}$ E.g. Judgment of the Court of 6 October 2015, Council v Commission, C-73/14, ECLI:EU: C:2015:663, paragraph 61 .

48، It is important for the management of the CFP to be guided by principles of good governance. Those principles include decision-making based on best available scientific advice, broad stakeholder involvement and a long-term perspective. The successful management of the CFP also depends on a clear definition of responsibilities at Union, regional, national and local levels and on the mutual compatibility of the measures taken and their consistency with other Union policies", Regulation 1380/2013, cit., recital 14.

49 "Sustainable exploitation of marine biological resources should be based on the precautionary approach, which derives from the precautionary principle referred to in the first subparagraph of Article 191(2) of the Treaty, taking into account available scientific data", Regulation (EU) No 1380/2013, cit., recital 10. See Proelss and Houghton (2012). And for a general reference about the precautionary principle in the EU see: European Commission, Communication from the Commission on the precautionary principle, COM (2000) 0001.

${ }^{50}$ Regulation 170/83, cit., recital 7; Regulation 3760/92 cit., recital 14; Regulation 2371/2002, cit., recital 37.

${ }^{51}$ Regulation 1380/2013, cit., recital 37.

${ }^{52}$ This was expressly stated by the CJEU. Judgment in case C-141/05, cit., paragraph 87.
} 
dimension is not hidden by the benefited parties. To the contrary, both Ireland ${ }^{53}$ and the $\mathrm{UK}^{54}$ appeal to it, and the MSs most strongly opposing the Hague Preferences because they are directly affected do not allege that the beneficiary regions are not dependent on fisheries or that there are other dependent regions that are left out. Rather, they argue that the Hague Preferences have altered the percentages negotiated in $1983 .{ }^{55}$

Although RS is a distribution key negotiated between the MSs of the EU, it does not operate as an agreement between parties imposed as mandatory according to international law but separate from EU law. The binding nature of RS does not derive from the pacta sunt servanda principle. Instead, it finds its legal basis in the secondary EU legislation, currently Regulation 1380/2013. So, as stated by the CJEU, RS will continue to apply until an amending regulation is adopted. ${ }^{56} \mathrm{RS}$ is an allocation that can be modified or repealed by an act of legislation. In this regard, as discussed above, during the last reform that culminated in Regulation 1380/2013, the Commission proposed amendments that finally did not come to fruition.

\section{The Discard Ban}

One of the negative effects of RS is the discards, which are catches returned to the sea (1). The new regulation imposes a progressive ban on discards but maintains RS as the distribution key for national quotas (2). The coexistence of both RS and the discard ban is a challenge for the first, not in its formal dimension as a quota allocation but in its substantive content on the utilization of the allocated quotas (3).

\footnotetext{
${ }^{53}$ During the debate prior to the latest reform of the CFP in 2010, Ireland stated that the Hague Preferences in Annex VII of the Hague Resolution were the counterpart to a concession that Ireland had made: access to their exclusive economic zone. It even claimed that it was "not possible to re-open or diminish the principles set out in Annex VII of the Hague Resolution without re-opening the whole issue of access within the 200 mile Exclusive Fisheries Zone". Government of Ireland, Ireland's response to the Commission's Green Paper on the Reform of the Common Fisheries Policy (Department of Agriculture, Fisheries and Food, 2010) 16; http://ec. europa.eu/fisheries/reform/docs/ireland_en.pdf.

${ }^{54}$ In the "Transcript of Minister for Europe David Lidington comments to media on the prospects of EU membership for a newly independent Scotland" (extracts from the interviews given to ITV Borders and BBC Scotland on 17 January 2014) published on the British government's website, Lidington warns: "if we look at the UK in the EU, we have got a good deal for Scotland. In terms of fisheries, the Shetland box, the Hague preferences, that wouldn't be guaranteed if Scotland walked away from the UK"; https://www.gov.uk/government/news/prospects-of-eu-membership-for-anewly-independent-scotland.

${ }^{55}$ These MSs have stated this on various occasions. For example, see the Statements published in the minutes of the Council, January 2008: "Statement by Belgium, Denmark, Germany and the Netherlands concerning the Hague Preferences" (p. 13) and "Statement by the French delegation...2. Implementation of the Hague Preferences" (p. 14); available at http://data. consilium.europa.eu/doc/document/ST-12272-2008-INIT/en/pdf.

${ }^{56}$ E.g., Judgment in case C-141/05, cit., paragraph 86.
} 


\subsection{Relative Stability and Discards}

The impact of discarding varies by species: some have low survivability when discarded (e.g., cod) whereas others may have higher survival rates (e.g., crustaceans). ${ }^{57}$ And discards have positive ecological effects to the extent that discarded fish is food for a range of scavenging species. ${ }^{58}$ However, discards are generally a negative practice entailing a massive waste of resources (human and animal food, potential income). In addition, it is probably the single most important reason for the poor quality of fisheriesdependent data that could be used to improve stock assessments. ${ }^{59}$

The nonrecording of discards makes it difficult to know the exact number of discards at a global or regional level, although we know it has reached worrying levels. ${ }^{60}$ In the EU, it varies from area to area, but it can be very high. ${ }^{61}$

The practice of discarding occurs for various reasons, which can be divided into two categories. ${ }^{62}$ First, discards occur for commercial reasons: wrong sex (where gender is important from a processing and marketing point of view); damaged fish, fish incompatible with the rest of the catch (slime or abrasion could cause damage to target species); inedible fish, rapidly spoiling fish; lack of space on board and high grading (take the best and leave the rest, often related to size). Second, discards also occur due to legal prohibitions: prohibited size, prohibited season, prohibited

\footnotetext{
${ }^{57}$ Andersen et al. (2014), p. 2.

${ }^{58}$ Food subsidies to wildlife as a result of human activity have an important effect on terrestrial and aquatic ecosystems, and intentional discarding at sea is recognized as one of the major global subsidies. Heath et al. (2014).

${ }^{59}$ Wilson and Jacobsen (2009), p. 6.

${ }^{60}$ In 1994, a study by the FAO-Alverson et al. (1994)—estimated that between 17.9 and 39.5 million tonnes (average, 27.0 million tonnes) of fish were discarded each year in commercial fisheries. In 2005 other study by the FAO_Kelleher (2005)—estimated that the weighted discard rate was $8 \%$ (proportion of the catch discarded). Based on this discard rate, the average yearly discards for the 1992-2001 period was estimated to be 7.3 million tonnes. The author warns that because of the different method used in this estimate, it was not directly comparable with the previous estimates of 27 million tonnes. In any case, the author states there was evidence to suggest a substantial reduction in discards in recent years. In geographical terms, the Northeast Atlantic (1.4 million tonnes), the Northwest Pacific (1.3 million tonnes) and the Western Central Atlantic (0.8 million tonnes) generated the highest discards.

${ }^{61}$ In 2011, the Commission created a compilation and review of information on the level of discarding in different fisheries within the EU. The Commission distinguished three categories: high discard fisheries $(>40 \%)$, medium discard fisheries $(15-39 \%)$, low discard $(<15 \%)$. In Table 2 (pp. 11-22), data per zone are shown: Region covered/Target Species/Discard rate/Main discarded species/Reason for discarding. The region with the highest percentage of discards was the Southern North Sea, with a discard rate of $71-95 \%$. Although within a region there may be very different discard practices according to species, for example: North Sea IV (English and Welsh fleets) had a general discard rate of 31\%, but $89 \%$ for Dub. European Commission (2011) Common Fisheries Policy Impact Assessment-EU Discards Annex. See also: Uhlmann et al. (2013).

${ }^{62} \mathrm{We}$ take as a reference, although simplifying some reasons and grouping them into two categories, the work of Lucas (1997).
} 
gear (a quota may be given for the capture of a particular species by a particular type of gear), prohibited fishing ground (closed for the capture of one species but open for others), prohibited species (no quota for the particular operator), and quotas reached (often the reason for high grading). This second category of discard occurs because the capture cannot be legally brought to market.

In the EU, prior to the current Regulation 1380/2013, it was not prohibited to discard fish, and discarded fish did not count towards an operator's quota. In this context, the national quota allocation system based on RS contributed to discarding, not because the EU's total TAC was used up but because the share for a particular MS was. While the fleet of one MS may not have used up its quota for a species, another fleet may have done so or may have had no quota at all, in which case this latter fleet would be forced to discard catches of this species. ${ }^{63}$ If all quota systems generate discards, the EU system multiplies discards as each national quota generates its own discarding constraints.

This situation is in the process of being eradicated as Regulation 1380/2013 imposes a progressive ban on discards. One of the main reasons for this change was the pressure of public opinion, from both inside and outside of the EU, which had been sparked by striking images in the media. ${ }^{64}$

\subsection{The Landing Obligation}

In accordance with Regulation 1380/2013, the discard ban is being introduced gradually (between 2015 and 2019) and on a fishery-by-fishery basis. ${ }^{65}$ The regulation distinguishes between four categories: small pelagic fisheries (e.g., mackerel, herring, horse mackerel, blue whiting, boarfish, anchovy, argentine, sardine, and sprat), large pelagic fisheries (e.g., bluefin tuna, swordfish, albacore tuna, bigeye tuna, blue and white marlin), fisheries for industrial purposes (e.g., capelin, sandeel, and Norwegian pout), species that define the fisheries (no examples of this category are given in the regulation). In addition to these categories, the regulation also describes certain species-area (inter alia fisheries for salmon in the Baltic Sea, fisheries for hake in the North Sea, etc.). It establishes four time frames that include these categories and species-areas and sets four deadlines by which the landing

\footnotetext{
${ }^{63}$ Green Paper 2009, cit., section 5.3.

${ }^{64}$ Borges (2015), p. 536, highlights an incident that took place in 2008. A UK trawler (The Prolific) was filmed by the Norwegian coastguard throwing five tonnes of fish overboard immediately after leaving Norwegian waters, where discarding is prohibited. This event was widely reported in the press. See, for example, the Guardian newspaper in its edition of 13/8/2008. Its online version even provides a video over $4 \mathrm{~min}$ long showing the operation in which the Prolific discarded nearly $80 \%$ of its catch. The boat had previously been inspected in Norwegian waters and declared legal, before crossing into UK waters where it dumped its load; http://www.theguardian.com/environ ment/2008/aug/13/fishing.endangeredspecies.

${ }^{65}$ Art. 15, Regulation 1380/2013, cit.
} 
obligation is to be effective (1 January 2015, 2016, 2017, and 2019). Without going into the details of which species or species-areas are included in each of these time frames, it is important to note that the EU discards affect the demersal species more than the pelagic species, ${ }^{66}$ which is why the implementation did not start with them.

So far, the Commission has adopted 5+3 plans. In October 2014, the Commission adopted five discard plans, applicable from 1 January 2015, for certain pelagic and industrial fisheries. ${ }^{67}$ One year later, in October 2015, the Commission adopted three discard plans, applicable from 1 January 2016, for certain demersal fisheries. ${ }^{68}$

The discard ban is established as a landing obligation. Catches during fishing activities in Union waters or by Union fishing vessels in international waters (waters not subject to EU or third countries' sovereignty or jurisdiction) must be brought and retained on board the fishing vessels, recorded, landed, and counted against any applicable quotas, except when used as live bait.

There are two possible exceptions to this obligation. First, the regulation allows for fishing operators to continue to discard species that, according to the best available scientific advice, have a high survival rate when released into the sea. ${ }^{69}$ For instance, an exemption from the landing obligation exists for Norway lobster caught in pots, traps, or creels in ICES division VIa and subarea VII. ${ }^{70}$ Second, to cater for unwanted catches that are unavoidable even when all measures for their reduction are taken, certain de minimis exemptions from the landing obligation may be established. ${ }^{71}$ For

\footnotetext{
${ }^{66}$ E.g. the discard rate in the North Sea has been $30-40 \%$ by weight for the main demersal fish species (cod, haddock, whiting and plaice) since the 1970s; and around 10\% for pelagic fish. Heath et al. (2014). ${ }^{67}$ Commission Delegated Regulation (EU) No 1392/2014 of 20 October 2014 establishing a discard plan for certain small pelagic fisheries in the Mediterranean Sea; Commission Delegated Regulation (EU) No 1393/2014 of 20 October 2014 establishing a discard plan for certain pelagic fisheries in north-western waters; Commission Delegated Regulation (EU) No 1394/2014 of 20 October 2014 establishing a discard plan for certain pelagic fisheries in south-western waters; Commission Delegated Regulation (EU) No 1395/2014 of 20 October 2014 establishing a discard plan for certain small pelagic fisheries and fisheries for industrial purposes in the North Sea; Commission Delegated Regulation (EU) No 1396/2014 of 20 October 2014 establishing a discard plan in the Baltic Sea. OJ 2014 L 370.

${ }^{68}$ Commission Delegated Regulation (EU) 2015/2438 of 12 October 2015 establishing a discard plan for certain demersal fisheries in north-western waters; Commission Delegated Regulation (EU) 2015/2439 of 12 October 2015 establishing a discard plan for certain demersal fisheries in south-western waters; Commission Delegated Regulation (EU) 2015/2440 of 22 October 2015 establishing a discard plan for certain demersal fisheries in the North Sea and in Union waters of ICES Division IIa. OJ 2015 L 336.

${ }^{69}$ Species for which scientific evidence demonstrates high survival rates, taking into account the characteristics of the gear, of the fishing practices and of the ecosystem. Regulation 1380/2013, cit., recital 27, article 15 paragraph 4.b.

${ }^{70}$ Article 2, Commission Delegated Regulation 2015/2438, cit.

${ }^{71}$ The de minimis exemption shall apply where scientific evidence indicates that increases in selectivity are very difficult to achieve; or to avoid disproportionate costs of handling unwanted catches, for those fishing gears where unwanted catches per fishing gear do not represent more than a certain percentage, to be established in a plan, of total annual catch of that gear. Regulation 1380/ 2013, cit., recital 31, article 15 paragraphs 4.c and 5.c.
} 
example, it exists a provision that allows to discard up to a maximum of $7 \%$ in 2015 and 2016, and 6\% in 2017 of albacore tuna for total annual catches in the albacore tuna directed fisheries using midwater pair trawls (PTM) in ICES sea area VII. ${ }^{72}$

In addition to these two possible exemptions, which are to be determined in the corresponding discard plan, fishing operators must discard catches of prohibited species (e.g., basking shark) ${ }^{73}$ and, since 2015 , also predator-damaged fish. ${ }^{74}$ These catches of prohibited species and predator-damaged fish cannot be retained on board and must be returned into the sea. ${ }^{75}$

These catches that can (high survivability, de minimis) or must (prohibited species, predator-damaged fish) be discarded are not counted against the quota, but they must be documented in the logbook. ${ }^{76}$

\subsection{Use of National Quotas}

The EU carries out a stock-by-stock management based on TACs (EU) and quotas (MSs). And, as we have seen, allocation keys were basically fixed for each stockarea on an MS basis when they joined the EU. Even if those allocation keys were adequate when fixed - a matter denied by some - the fact is that, as the Commission points out, conditions have changed since then due to different factors as, not intending to be exhaustive, stock development, the evolution of fleets, new fishing strategies on different stocks, changes in demand for given species, or the evolution of imports. ${ }^{77}$ One of the effects of this system is the so-called mini-quotas. ${ }^{78}$

\footnotetext{
${ }^{72}$ Article 3.a, Commission Delegated Regulation 1393/2014, cit.

${ }^{73}$ Species in respect of which fishing is prohibited and which are identified as such in a Union legal act adopted in the area of the CFP. Regulation 1380/2013, cit., recital 27, article 15 paragraph 4.a.

${ }^{74}$ Fish which have been damaged by predators such as fish-eating marine mammals, predatory fish or birds, can constitute a risk to humans, to pets and to other fish by virtue of pathogens and bacteria which might be transmitted by such predators. This fish is a new exception to the landing obligation inserted by Regulation (EU) 2015/812 of the European Parliament and of the Council of 20 may 2015 amending, among others, Regulation (EU) No 1380/2013. JO 2015 L 133, recital 16 and art. 9.a.

${ }^{75}$ European Commission, “1 January 2015: the landing obligation”, http://ec.europa.eu/fisheries/ cfp/fishing_rules/landing-obligation/index_en.htm.

${ }^{76}$ Ibid.

${ }^{77}$ European Commission (2011) Impact assessment; Commission staff working paper accompanying the document Commission proposal for a Regulation of the European Parliament and of the Council on the Common Fisheries Policy; IA 2011, hereinafter. SEC (2011) 891 final, de 13.7.2011; Section 2.1.4.

${ }^{78}$ During the discussions prior to the last reform of the CFP, Ireland manifested its support for RS but also proposed a relaxation of it. One of the problems that Ireland pointed out was the miniquotas: “(...) While these allocations may reflect catch history in the 1970's, today they are very small quotas in often distant fisheries. In many cases fleets steam many miles (incurring significant carbon foot prints) to catch small allocations in fisheries where they may or may not also have
} 
There are two ways of easing RS. MSs may exchange all or part of the fishing opportunities allocated to them, ${ }^{79}$ or they may make use a year-to-year flexibility mechanism of up to $10 \%$ of their permitted landings. ${ }^{80}$ Outside of these two options, overfishing is penalized. When the Commission establishes that a MS exceeded the quotas which have been allocated to it, the Commission shall operate deductions in the future quotas of that MS by applying a multiplying factor. ${ }^{81}$ For this reason, some exchanges of quotas between MSs are actually regularizations in disguise. ${ }^{82}$

Quota exchanges take place between $\mathrm{MSs}^{83}$ but not in a fully satisfactory manner, so quotas sometimes have been underutilized. ${ }^{84}$ This has been the situation so far, and in the current period it is expected to worsen as a result of the ban on discards.

At this point in time, the traditional mechanisms for providing RS flexibility are still in place and, as we have seen, the landing obligation is in force with some exemptions. In addition are two further elements: discards are taken into account when setting quotas for MSs, and a new flexibility mechanism has been introduced. Indeed, on the one hand, when the landing obligation for a fish stock is introduced, fishing opportunities will be fixed taking into account the change from fixing fishing opportunities that reflect landings to fixing fishing opportunities that reflect catches, given that, for the first and subsequent years, discarding of that stock will no longer be allowed. ${ }^{85}$ In other words, in a scenario with discards, the reference is landings

quotas for other stocks caught in mixed fisheries. Given their size it is evident that it is not commercially viable to catch these quotas; indeed many of them are economically unsound and should be redistributed to Member States in a position to utilize them (...)." Department of Agriculture, Fisheries and Food of the Government of Ireland (2010), Ireland's Response to the Commission's Green Paper on the Reform of the Common Fisheries Policy, pp. 16-17, section 3.3.1; http://ec.europa.eu/fisheries/reform/docs/ireland_en.pdf.

${ }^{79}$ Regulation 1380/2013, cit., recital 29 and Art. 16.8.

${ }^{80}$ Ibid., Art. 15.9.

${ }^{81}$ Article 105, Council Regulation (EC) No 1224/2009 of 20 November 2009; JO 2009 L 343.

${ }^{82}$ Commission warned some years ago (IA 2011, cit., Section 2.1.4) that the Commission got close to 1000 notifications of swaps per year, $50 \%$ of which were nearly permanent, the rest were late year 'regularisations' intended to legitimise excessive catches.

${ }^{83}$ As the Commission informed (ibid.), MSs exchanged more than $10 \%$ of their quotas in the period 2005-2008 on an annual basis. The species with the highest swap volumes were redfish, cod and hake and some pelagic species like herring, blue whiting, jack mackerel, mackerel, sprat, anchovy and sandeel.

${ }^{84}$ The Vessels' Owners Cooperative of the Spanish Port of Vigo España (ARVI) conducted a study on the situation. The study analyzes 20 major species subject to quotas in the EU for the period 2008-2014. The report concludes (pp. 52-53) that the remaining portion of the quota that was not eventually utilized by MSs amounted to 1 million tonnes (exactly 1,039,549.78 tonnes) over the period 2008-2014, i.e., an average of 23\% (an annual average of roughly 143 thousand tonnes). These underutilized quotas represented a total value of 1833.7 million euros (based on the guide prices). ARVI (2016) Update of the TAC and quota system in face of the ban of discards; SpanishEnglish bilingual edition, http://www.arvi.org/publicaciones/PuestaTacsCuotasDescartes.pdf.

${ }^{85}$ Regulation 1380/2013, cit., Art. 16.2. 
(catches less discards), while when discards are prohibited, the reference is the catches (discounting catches not subject to the landing obligation). On the other hand, flexibility between species is allowed. Catches of species that are subject to the landing obligation and that are caught in excess of quotas of the stocks in question, or catches of species in respect of which the MS has no quota, may be deducted from the quota of the target species provided that they do not exceed $9 \%$ of the quota of the target species. ${ }^{86}$ This second possibility-flexibility between species- has been seen by some as a breach of RS in favor of the autonomy of MSs, as it allows applying not used-up quotas to other species for which there is no quota, or for which quotas have been exceeded. ${ }^{87}$

In summary, RS maintains its flexibility mechanisms (quota swapping and yearto-year flexibility), the landing obligation is not absolute (with the exemptions of high survivability, de minimis, prohibited species, and predator-damaged fish), the fishing opportunities that take into account the effect of discards are expected to increase, and some flexibility between species will be admitted. Will this be enough?

The biggest concern is with the so-called choke species, which may even further reduce quota exchanges. MSs that previously got rid of certain quotas will now need them to cover the discard ban to prevent that other species strangle the catches of its target species. The real challenges lie with the demersal species. Although we will have to wait to see what happens on the fishing grounds, the experience with pelagic species has not been encouraging. In this case, the choke species have not stimulated quota exchanges but rather reduced them. ${ }^{88}$

At this point, it should be remembered that one of the objectives of the CFP is to increase productivity in fisheries by ensuring the rational development of fisheries production and the optimum utilization of the factors of production, in particular labor. ${ }^{89}$ A notion that must be understood in the light of other objectives, which include a fair standard of living for the fishing community and supply at reasonable prices.

This management of resources must also take into account the peculiarities resulting from structural and natural disparities between the various fishing regions,

\footnotetext{
${ }^{86}$ This provision only applies where the stock of the non-target species is within safe biological limits. Regulation 1380/2013, cit., Art. 15.8.

${ }^{87}$ E.g. Spanish Government; interview with Carlos Dominguez, at the moment Secretary General for Fisheries of the Government of Spain; published in March 2013 and reported in various media; see La Opinion in its edition of 19.03.2013, http://www.laopinioncoruna.es/mar/2013/03/18/car los-dominguez-plan-descartes-reducira-pesca-gran-sol-tres-meses-ano/703190.html.

${ }^{88}$ With regard to the issue of choke species and quota swaps, European Commission informs that stakeholders are suggesting that MSs seem to retain quotas rather than increase swapping under the newly introduced landing obligation. Commission staff working document accompanying the document: Communication from the Commission to the European Parliament and the CouncilConsultation on the fishing opportunities for 2017 under the Common Fisheries Policy; COM (2016) 396 final, 15.06.2016, p. 10.

${ }^{89}$ And also by promoting technical progress, but it is not what we want to emphasize now.
} 
the impact of the fisheries sector on the whole economy, and the need to effect the appropriate adjustments by degrees. ${ }^{90}$

As the fisheries sector points out, for years discards were socially and politically accepted. When this ceased to be the case, the need arose to ban them. Likewise, there may come a day when the socioeconomic effects of the inability to take advantage of fishing quotas also become socially and politically intolerable. We understand that this is especially relevant to fishing-dependent regions, understanding this category of regions not in the sense of the Hague Preferences formula, which is limited to Ireland and the UK, but in a genuine sense to include all fishingdependent regions of the EU. ${ }^{91}$ Good examples, although not the only ones, of regions in this category are Galicia (Spain), Highlands and Islands (UK), N-E Scotland (UK), Algarve (Portugal), and Peloponnisos (Greece). ${ }^{92}$

\section{Final Considerations}

Perhaps much of the frustration that RS has generated over the years in some states - mainly in states adversely affected like Spain-derives from the misleading way it has been formulated. The mismatch between the formulation of the RS concept and the concrete allocation of fishing opportunities among MSs, which has been applied annually for more than 30 years, has led some to consider that the concrete allocation constitutes a breach of the RS and hence a breach of EU law. But despite that RS is formulated as a system based on historical catches that also takes into account the needs of regions particularly dependent on fisheries, the fact is that both considerations serve only as a partial explanation of what RS actually is. As the CJEU has stated, "requirement of relative stability must be understood as meaning that each Member State is to retain a fixed percentage when fishing

\footnotetext{
${ }^{90}$ See art. 39 TFEU. This article sets out the objectives of the common agricultural policy. However, it should be noted that, as occurs in the art. 38.1 TFEU, references to the common agricultural policy or to agriculture, and the use of the term "agricultural", must be understood as also referring to fisheries.

${ }^{91}$ See Natale et al. (2013). The authors identify and map specific local communities in which, given the conditions of accessibility, employment and size of the fishing fleet, the dependence on fishing activities can be considered particularly relevant, i.e., with ratios above 5\%. See also European Commission, Facts and figures on the Common Fisheries Policy-Basic statistical data (European Union, Luxembourg, 2014).

${ }^{92}$ European Parliament (2007) Regional dependency on Fisheries, IP/B/PECH/ST/IC/2006-198; study requested by the European Parliament's Committee on Fisheries and carried out by Pavel Salz and Graeme Macfadyen. E.g. combining income dependency on the fisheries sector and the number employed, the top five-ranked NUTS-2 regions were Galicia (Spain), Highlands and Islands (UK), N-E Scotland (UK), Algarve (Portugal) and Peloponnisos (Greece); see table 11, pp. 17-18. About Galicia, see Surís-Regueiro and Santiago (2014); also the latest report published by the Galician Statistics Institute: "Analisis do Sector da Pesca", 2015, http://www. ige.eu/estatico/pdfs/s3/publicaciones/AnaliseSectorPesca.pdf.
} 
opportunities are distributed" and "the distribution formula originally laid down ... will continue to apply as long as an amending regulation has not been adopted,"93 which has yet to occur. States have been negotiating the distribution key for years (mainly in 1983 but also in subsequent acts of accession and whenever it has been necessary to allocate quotas for new fishing opportunities). It is a fixed percentage, only altered annually when appropriate by applying the Hague Preferences. Therefore, in our opinion, the arguments that this allocation key identified as RS is not a true reflection of historical catches of MSs, or it does not take into account the needs of all regions particularly dependent on fisheries, probably do not provide a sufficient legal ground for questioning its legality. However, they may be good arguments for negotiation within the framework of a reform process.

One of the effects of RS is discards, i.e., catches returned to the sea. The current legislation, Regulation 1380/2013, keeps RS as a criterion for allocating fishing opportunities among MSs but introduces a gradual ban on discards. Aside from the existing flexibility mechanisms of RS (quota swapping and year-to-year flexibility), Regulation 1380/2013 establishes some exemptions to the landing obligation (high survivability, de minimis, prohibited species, and predator-damaged fish), provides an additional mechanism of flexibility (between species), and allows an increase in fishing opportunities to take into account the effect of discards.

The challenge is great, especially in certain mixed fisheries where the discard rate is very high. At this stage at least, it appears that RS could be the loser in the compromise sought in Regulation 1380/2013 between it and the discard ban. Exactly to what extent the RS is affected will depend on how insufficient the regulation's mechanisms turn out to be and whether any further corrective action is taken. RS will continue to be the distribution key, but the MSs could not be able to satisfactorily use their quotas. While national quotas were not being fully used prior to the ban on discards, mainly due to deficiencies in quota swapping, the discard ban might not improve this. Although we are still at the implementation phase, and the real challenge is with the demersal species, the experience with pelagic species seems to indicate no increase in quota swapping and so far is having exactly the opposite effect.

From a legal point of view, to what extent is it relevant that MSs cannot fully exploit their fishing quotas? To answer this question, we need to keep in mind the objectives of the CFP. The EU has to increase productivity in fisheries by ensuring the rational development of fisheries production and the optimum utilization of the factors of production, in particular labor. The EU has to exploit fisheries resources in such a way that ensures the sustainability of marine ecosystems and also provides reasonable income to those who depend on fishing activities while taking into account the interests of consumers. The inability of a state to fully use their fishing quotas clearly has a negative effect on those who make a living from fishing, and also on the price and supply. This effect is logically more damaging in fishingdependent regions, a category that should be freed from the shackles of the Hague

\footnotetext{
${ }^{93}$ Judgments in cases C-87/03 and C-100/03, cit., paragraph 27.
} 
Preferences, which strips it of its substance by restricting it to regions in two MSs (Ireland and the UK) while, in its true sense, this category includes many other regions.

\section{References}

Alverson DL, Freeberg MH, Pope JG, Murawski SA (1994) A global assessment of fisheries bycatch and discards. FAO fisheries technical paper no. 339

Andersen P, Andersen J, Mardle S (2014) What's going to happen with the CFP Reform discard policy? In: Conference papers and presentations of the 17th IIFET conference, International Institute of Fisheries Economics and Trade (IIFET), Brisbane, 7-11 July 2014

Borges L (2015) The evolution of a discard policy in Europe. Fish Fisheries 16(3):534-540

Churchill R, Owen D (2010) The EC Common Fisheries Policy. Oxford University Press, Oxford

Del Vecchio A (1982) Sull'incidenza della normativa comunitaria sui tratati in materia di pesca fra Stati membri della CEE e Stati terzi. Rivista di diritto internazionale 65:571-582

Franckx E (2012) Sea fisheries cases before the European Court of Justice. In: Wolfrum R (ed) Max Planck Encyclopedia of Public International Law. Oxford University Press, Oxford, pp 42-47

Heath MR, Cook RM, Cameron AI, Morris DJ, Speirs DC (2014) Cascading ecological effects of eliminating fishery discards. Nat Commun 5:1-8. doi:10.1038/ncomms4893

Holden MJ (1985) The procedures followed and the problems met by the European Economic Community in implementing the scientific recommendations of the International Council for the exploration of the sea on total allowable catches. In: Papers presented at the expert consultation on the regulation of fishing effort (fishing mortality), Rome, 17-26 January 1983. FAO Fisheries Rep 289(3):215-470

Kelleher K (2005) Discards in the World's Marine Fisheries. An update. In: FAO fisheries technical paper no. 470. FAO, Rome

Le Bihan D (2003) La jurisprudence communautaire et le principe de stabilite relative dans la politique commune de la pêche. In: Cudennec A, Gueguen-Hallouet G (eds) Le juge communautaire et la mer. Bruylant, Brussels, pp 143-160

Lostado i Bojo R (1985) La Política Común de la Pesca en la CEE y España. Revista de Estudios Agro-Sociales 131:39-69

Lucas I (1997) A study of the options for utilization of by catch and discards from marine capture fisheries. In: FAO fisheries circular no. 928 FIIU/C928. FAO, Rome

Meseguer Sánchez JL (1981) El Derecho comunitario y los derechos de pesca de los Terceros Países. Revista de Instituciones Europeas 8(1):53-65

Natale F, Carvalho N, Harrop M, Guillen J, Frangoudes K (2013) Identifying fisheries dependent communities in EU coastal areas. Mar Policy 42:245-252

Penas Lado E (2016) The Common Fisheries Policy: the quest for sustainability. Wiley-Blackwell

Proelss A, Houghton K (2012) The EU Common Fisheries Policy in light of the precautionary principle. Ocean Coastal Manag 70:22-30

Rey Aneiros A (2001) La Unión Europea frente a las transformaciones del Derecho internacional de la pesca. Tirant lo Blanch, Valencia

Sobrido-Prieto M (2013) Los jueces españoles en su papel de jueces comunitarios: el intercambio de cuotas pesqueras de anchoa en el Golfo de Vizcaya y el principio de estabilidad relativa en las sentencias del tribunal de Luxemburgo, de la Audiencia Nacional y del Tribunal Supremo. Revista de Derecho comunitario europeo 45:691-718

Sobrino Heredia JM (1990) Les Accords de pêche conclus par l'Espagne et les pays en voie de développement. In: Velas P (ed) Aspects du droit international économique. Pedone, Paris, pp 203-237 
Sobrino Heredia JM (2003) La participación de la Unión Europea en las transformaciones del Derecho de Pesca. Cuadernos de derecho pesquero 2:77-98

Sobrino Heredia JM (2009) La politique communautaire de conservation et gestion des ressources halieutiques et quelques problèmes concernant l'application du droit de l'Union européenne. In: Casado Raigón R, Cataldi G (eds) L'évolution et l'état actuel du droit international de la mer. Mélanges de droit de la mer offerts à Daniel Vignes. Bruylant, Bruxelles, pp 865-885

Sobrino Heredia JM, Rey Aneiros A (1997) La Jurisprudencia del Tribunal de Justicia de las Comunidades Europeas sobre la Política Común de la Pesca. Xunta de Galicia, Santiago de Compostela

Surís-Regueiro JC, Santiago JL (2014) Characterization of fisheries dependence in Galicia (Spain). Mar Policy 47:99-109

Treves T (1976) La Communauté européenne et la zone économique exclusive. Annuaire français de droit international 22(1):653-677

Uhlmann SS, van Helmond ATM, Stefánsdóttir EK, Sigurðardóttir S, Haralabous J, Maria Bellido J, Carbonell A, Catchpole T, Damalas D, Fauconnet L, Feekings J, Garcia T, Madsen N, Mallold S, Margeirsson S, Palialexis A, Readdy L, Valeiras J, Vassilopoulou V, Rochet M-J (2013) Discarded fish in European waters: general patterns and contrasts. ICES J Mar Sci: 1-11. doi:10.1093/icesjms/fst030

Wilson DC, Jacobsen RB (2009) Governance issues in mixed-fisheries management: an analysis of stakeholder views. IFM-Innovative Fisheries Management, Aalborg University, Aalborg

Open Access This chapter is licensed under the terms of the Creative Commons AttributionNonCommercial 4.0 International License (http://creativecommons.org/licenses/by-nc/4.0/), which permits any noncommercial use, sharing, adaptation, distribution and reproduction in any medium or format, as long as you give appropriate credit to the original author(s) and the source, provide a link to the Creative Commons license and indicate if changes were made.

The images or other third party material in this chapter are included in the chapter's Creative Commons license, unless indicated otherwise in a credit line to the material. If material is not included in the chapter's Creative Commons license and your intended use is not permitted by statutory regulation or exceeds the permitted use, you will need to obtain permission directly from the copyright holder. 